\begin{tabular}{|c|c|}
\hline \multirow{3}{*}{ 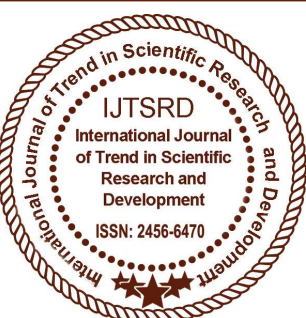 } & $\begin{array}{l}\text { International Journal of Trend in Scientific } \\
\text { Research and Development (IJTSRD) }\end{array}$ \\
\hline & International Open Access Journal \\
\hline & ISSN No: 2456 - 6470 | www.ijtsrd.com | Volume - 2 | Issue - 5 \\
\hline
\end{tabular}

\title{
Design of High Strength Concrete Using Superplastisizer and Stone Dust
}

\author{
Rayees Ahmad Bhat ${ }^{1}$, Mr. Misba Danish ${ }^{2}$ \\ ${ }^{1}$ Student, ${ }^{2}$ Assistant Professor \\ Department of Civil Engineering, Al-Falah School of Engineering and Technology \\ Al-Falah University, Faridabad, Haryana, India
}

\begin{abstract}
Concrete is the most widely used construction material today. Increase in construction activities have led to an increase in demand for the various raw materials in concrete, especially river sand which is the conventionally used fine aggregate. Due to increase in mining process, the availability of this river sand is becoming scarce. This led to researches on alternate materials as ingredients of concrete that are in no way inferior to the conventional materials. Manufactured sand was one of the alternate materials proposed. Though manufactured sand has many advantages, one of the major areas of concern is the fine material of size 150 micron and down removed during the manufacturing process and accumulated as a waste material. The paper presents the laboratory investigations and a comparative study on the mechanical properties and behaviour of high strength concrete an mortar using fine stone dust, the residue produced during the production of manufactured sand.
\end{abstract}

Keywords: high strength concrete, stone dust, super plasticizers, compressive strength, flexural strength, creeping.

\section{INTRODUCTION}

\subsection{GENRAL}

As the use of super plasticizers gains widespread acceptance around the world and the need for proper guidelines for its use becomes a necessity. The difficulty in using admixture results from the fact that its effect on concrete depend on a number of factors including mix proportions, ambient Temperature, time of addition, dosage of admixture and mixing time. In order to produce quality durable concrete such guidelines have to be developed. High-range water reducers (HRWR), commonly referred to as super plasticizers, are chemical admixtures that can be

added to ready-mix concrete to improve its plastic and hardened properties. They are also known as super fluidizers super fluidifizers and super water reducers. The first super plasticizers were developed in 1964 by Kenichi Hattori in Japan. It was based on formaldehyde condensates of beta-naphthalene sulfonates. Later that same year, a super plasticizer based on sulfonated melamine formaldehyde condensate was introduced in West Germany under the name Mlmet.

High-range water reducers are capable of reducing the water requirement for a given slump by about $30 \%$, thus producing quality concrete having higher strength and lower permeability. They present important advantages compared to conventional water reducers which only allow a reduction of up to $15 \%$. Further, water reduction using water reducers would result in segregation of the fresh mix and a reduced degree of hydration at a later age.

The cost of super plasticizers is quite significant at about Rs.120 per liter. Despite its cost, tremendous savings in labor and production costs can be achieved by using the admixture.

Super pasticizers are chemical admixtures capable of improving the workability of concrete without affecting its water/cement ratio.

They are classified into four groups:
$>$ Sulphonated melamine-formaldehyde condensate(SMF)
$>$ Sulfonated condensate(SNF) naphthalene-formaldehyde Modified lingo sulfonates(MLS) 
Other sulphonic-acid esters, and carbohydrate esters.

\subsection{BACKGROUND}

In Japan high strength concrete was first achieved as early as the 1930s. Yoshida reported in 1930 that high strength concrete with 28-day compressive strength of $102 \mathrm{MPa}$ was obtained. This result was obtained by a combination of pressing and vibrating processes without the use of any chemical and mineral admixtures. This method has been applied for production of high strength segments. In the 1960s, super plasticizers were developed in Japan and West Germany which were very effective chemical admixtures to decrease the water content in concrete. With the use of super plasticizers, it became possible to decrease the water to cement ratio while maintaining the workability of the concrete. This technique was applied very widely and many bridges, high-rise buildings, precast concrete members have been produced. In the 1970s, the combined use of super plasticizers and ultra-fine materials such as silica fume, finely ground blast furnace slag or anhydrous gypsum based additives were studied and has been applied to concrete structures until today. Finally, super high strength concrete greater than 120 $\mathrm{MPa}$ in compressive strength was achieved with selected materials and special techniques and this kind of concrete has been applied in other industries instead of in the construction industry.

\subsection{OBJECTIVES OF THE PROJECT}

1. To investigate different alternatives for developing High strength concrete

2. To find the optimum percentage of stone and super plastisizers that need to be substituted in place of cement.

3. The overall goals of this research are to improve the concrete mix design .

4. The main objective of the project is to get maximum compressive strength without altering the properties of concrete

5. In most of cases we have seen that while adding stone dust the workability changes with percentage so we have to find the optimum percentage of stone dust to be added at which the compressive strength is maximum

6. All the mix design should be as per is code 10262:2009

7. Objective of mixing the plasticizers with concrete should improve the workability of concrete without affecting $\mathrm{w} / \mathrm{c}$ ratio
8. Practical use of plasticizer in concrete is in reducing amount of water required by up to $30 \%$ while keeping the same workability.

\section{LITERATURE REVIEW}

\subsection{Behaviour of High Strength Concrete Using Cement Kiln Dust and Silica Fume. OSR Journal of Mechanical and Civil Engineering (IOSR- JMCE) e-ISSN: 2278 1684,p-ISSN: 2320-334X, Volume 14, Issue 2 Ver. V II (Mar. -Apr. 2017), PP 2326 www.iosrjournals.org}

This research concludes following results.

\section{Compressive Strength Results:}

With $0 \%$ CKD the basic M40 concrete has given the design strength of $48.49 \mathrm{MPa}$ at 28 days and with $5 \%$ Silica Fume the strength has gone up-to $50.90 \mathrm{MPa}$ and with $10 \%$ Silica Fume the strength has gone up to 54.90MPa. To further increase the strength properties of concrete combination of $\mathrm{CKD}$ with $\mathrm{SF}$ is tried in the present project work. With $10 \% \mathrm{CKD}$ and $5 \% \mathrm{SF}$ the strength is going up to $56.10 \mathrm{MPa}$, with $10 \%$ CKD and $10 \%$ SF the strength is further going up-to $58 \mathrm{MPa}$. Similarly With $20 \% \mathrm{CKD}$ and 5\% CSF the strength is reduced to $47 \mathrm{MPa}$, with $20 \% \mathrm{CKD}$ and $10 \%$ SF the strength is $39 \mathrm{MPa}$ Split Tensile Strength Of Cement Kiln Dust and Silica Fume Concrete

\section{Split Tensile Strength Results}

With $0 \%$ CKD and $0 \%$ SF the basic M40 concrete has given design strength of $4 \mathrm{MPa}$ at 28 days. With 5\% Silica Fume the strength has gone up-to 4.20 MPa and with $10 \%$ Silica Fume the strength has further gone up to $4.38 \mathrm{MPa}$. With CKD10\% and $5 \%$ CSF the strength is going up to $4.45 \mathrm{MPa}$ and with CKD10\% and $10 \% \mathrm{SF}$ the strength is further going up to 4.56MPa. Similarly With $20 \% \mathrm{CKD}$ and 5\% SF the strength is reduced to $4.13 \mathrm{MPa}$, with $20 \% \mathrm{CKD}$ and $10 \% \mathrm{SF}$ the strength is $4.04 \mathrm{MPa}$

\subsection{EFFECT OF STONE DUST AND FINES ON THE PROPERTIES OF HIGH STRENGTH SELF COMPACTING CONCRETE International Journal of Civil Engineering and Technology (IJCIET) Volume 7, Issue 6, November-December 2016,pp. 393-399,}

The following are the conclusions obtained from this research. 
$>$ The optimum fine aggregate replacement with stone d ust quantity is $40 \%$.

$>$ Increase in the fly ash content in the total powder in the optimized stone dust mix the slump flow vfunnel values are increases.

$>$ With increase in fly ash content in the total powder the rate of increase in strength is not affected at 3 days, 7 days but affected at 28 days due to pozzalanic action.

$>$ The optimum fly ash content in $60 \mathrm{Mpa} \mathrm{SCC}$ is $30 \%$ in total powder content.

\subsection{Experimental Investigation on High} Performance Concrete with Partial Replacement of Cement by Fly Ash and Fully Replacement of Sand by Stone Dust. International Journal of Constructive Research in Civil Engineering (IJCRCE) Volume 1, Issue 1, June 2015, PP 8-13 www.arcjournals.org

This paper concludes that $\mathrm{n}$ this the Concrete Mix M40 has been designed as 1:2.43:0.78:0.35. The concrete with optimum replacement percentage of $25 \%$ replacement of cement by fly ash and $100 \%$ fully replacements of fine aggregate by Stone dust in concrete mix quantities also arrived. The slump value for M40 grade using Stone dust and fly ash gets increased, when $100 \%$ replacement of Stone dust and $25 \%$ replacement of fly ash with $1.2 \%$ super plasticizer. Hence fly ash and stone dust replacement is effective for HPC in order to attain high strength. Compare to nominal concrete M40grade concrete attain increase \% strength by using lower water/binder ratio. Also reduce the segregation and bleeding

\subsection{Optimum usage of Using Met kaolin and} Quarry Dust in High Performance Concrete. IOSR Journal of Engineering (IOSRJEN) www.iosrjen.org ISSN (e): 2250-3021, ISSN (p): 2278-8719Vol. 04, Issue 02(February. 2014), ||V1|| PP 56-59

Based on the results the compressive and split tensile strengths are increased by mixing of Met kaolin with Quarry Dust. From the above experimental results it is proved that, Quarry Dust can be used as alternative material for the fine aggregate (sand). And Met kaolin can be used as one of the alternative material for the cement used for producing HPC.. Based on the results the compressive and split tensile strengths are increased by mixingof Metakaolin with Quarry Dust.
2.5 Effective Utilization of Crusher Dust in Concrete Using Portland Pozzolana Cement International Journal of Scientific and Research Publications, Volume 3, Issue 8, August 2013 ISSN 2250-3153

The compressive strength of M25 concrete mix had increased by $22 \%$ with the use of crusher dust at $40 \%$ replacement of natural sand. The compressive strength of all mixes i.e., a partial replacement of natural sand with crusher dust at the levels of $30 \%$, $40 \%, 50 \%$ and $60 \%$ showed an increase in compressive strength by $8.26 \%, 22.34 \%, 18.53 \%$ and $4.9 \%$ respectively. The compressive strength of M30 concrete mix had increased by $16 \%$ with the use of $40 \%$ replacement of natural sand by crusher dust. The compressive strength of all mixes i.e., a partial replacement of natural sand with crusher dust at the levels of $30 \%, 40 \%, 50 \%$ and $60 \%$ showed an increase in compressive strength by $5.25 \%, 16 \%, 12.5 \%$ and $8.9 \%$ respectively.

2.6 Behavior of Concrete on Replacement of Sand with Quaries Stone Dust as Fine Aggregate. International Journal of Innovative Research in Science, Engineering and Technology (An ISO 3297: 2007 Certified Organization) Vol. 4, Issue 1, January 2015. ISSN (Online): 2319 -8753 ISSN (Print) :2347 $-6710$

This paper concludes that for the designed mix proportions of M25 and M40 grades of concrete the desired characteristic strengths for cubes are achieved in both conventional concrete and Quarry Stone dust concrete. The strength achieved in concrete made with sand as fine aggregate achieved high strengths when compared with Quarry stone dust concrete. However, in both the cases strengths were falling at a super plasticizer dosage of $1.3 \%$ by weight of cement. Similar behavior was also observed in cubes of M40 grade cubes. In M40 grade cubes it was observed that at $1.3 \%$ dosage of super plasticizer the compressive strength is decreased.

\subsection{Use of Stone Dust as Replacement of Fine Aggregate in Concrete-Review. International Journal of Innovative and Emerging Research in Engineering Volume 3, Issue 9, 2016 e- ISSN: $2394-3343$}

This research is done on various papers and it concludes that: 
$>$ The idea revolves around the concept of utilization of stone dust by replacement of fine aggregate i.e. sand. The most of experiments performed are based on partial replacement of sand by stone dust at varying percentages and finding the optimum stone dust contents with minimum undesirable results, however few also tried full replacement of sand contents. Most of the researchers have restricted their work to analyze the compressive strength, the specific concrete property which does not reflect the true behavior of concrete; however few have also tested for other parameters like elastic modulus, abrasion, tensile strength, flexural strength and durability etc.

$>$ The most of the research has been done on ordinary strength concrete and the aspect of High Strength/high performance concrete has very little been touched upon.

$>$ The use of pozolanic material in concrete mix containing stone dust has not been studied. The aspect is expected to yield positive results.

$>$ The research has been vaguely referring to stone dust as a common by product of rock crushing, whereas there is a wide variation in basic characteristics of stone dust from different quarry sites. The aspect of standardization in terms of particle size analysis, the composition and presence of any deleterious contents etc have not been studied. Hence it is not possible to compare the results of stone dust in one area to stone dust of other area.

$>$ Material selection is a primary area of research, future studies require to lay more emphasis on selection process to arrive on conclusive parameters for selection of best material.

\subsection{Development of High Strength Self Curing} Concrete Using Super Absorbing Polymer K. Bala Subramanian, A. Siva, S. Swaminathan, Arul. M. G. Aji www.waset.org

From this investigation of the authors, the following could be concluded.

1. Desired strength characteristics and Rapid chloride permeability properties results were obtained by using Polyethylene Glycol as Selfcuring agent.

2. From the workability test results, it was found that the self-curing agent improved Workability.

3. For High Strength Concrete, the strength development of concrete is more if the replacement percentage of silica fume by weight of cement is $10 \%$ but Rapid chloride permeability of the concrete decreases if the replacement percentage of silica fume by weight of cement is $15 \%$.

4. The Strength of the concrete increases significantly with the increase of self-curing agent. i.e., concrete with $0.4 \%$ of $\mathrm{PEG}$ gives more strength than that with $0.2 \%$, and $0.3 \%$

\subsection{Study on Strength of Concrete by Partial} Replacement of Fine Aggregate with M-Sand and Late rite with Super plasticizers. International Journal of Engineering Trends and Technology (IJETT) -Volume 38 Number 8-August 2016

This paper concludes that

> The compressive strength with $20 \%$ replacement of natural sand by late rite sand reveals higher strength.

The split tensile strength with $20 \%$ replacement of natural sand by late rite sand reveals higher strength.

The flexural strength with $20 \%$ replacement of natural sand by late rite sand reveals higher strength hence overall strength of M20 grade concrete increases with $20 \%$ of natural sand by late rite sand

The compressive strength with $40 \%$ replacement of natural sand by manufactured sand reveals higher strength

The split tensile strength with $40 \%$ replacement of natural sand by manufactured sand reveals higher strength

2.10 An experimental study on high performance concrete using mineral admixtures (C) 2017 IJEDR | Volume 5, Issue 2 | ISSN: 2321-9939

Compressive strength for concrete with replacement of natural sand of foundry sand 10,20, and $30 \%$ and cement by mineral admixtures is fly ash10, 20, and $30 \%$ and GGBS is 10,15 and $20 \%$.

The compressive strength continue to increase as the curing period increase and greatest compressive strength is achieved when mixture content $30 \%$ of fine aggregate replaced with foundry sand and $10 \%$ GGBS 


\section{METHODOLOGY}

The methodology adopted for achieving the desired objectives is shown in the form of flow chart given below:

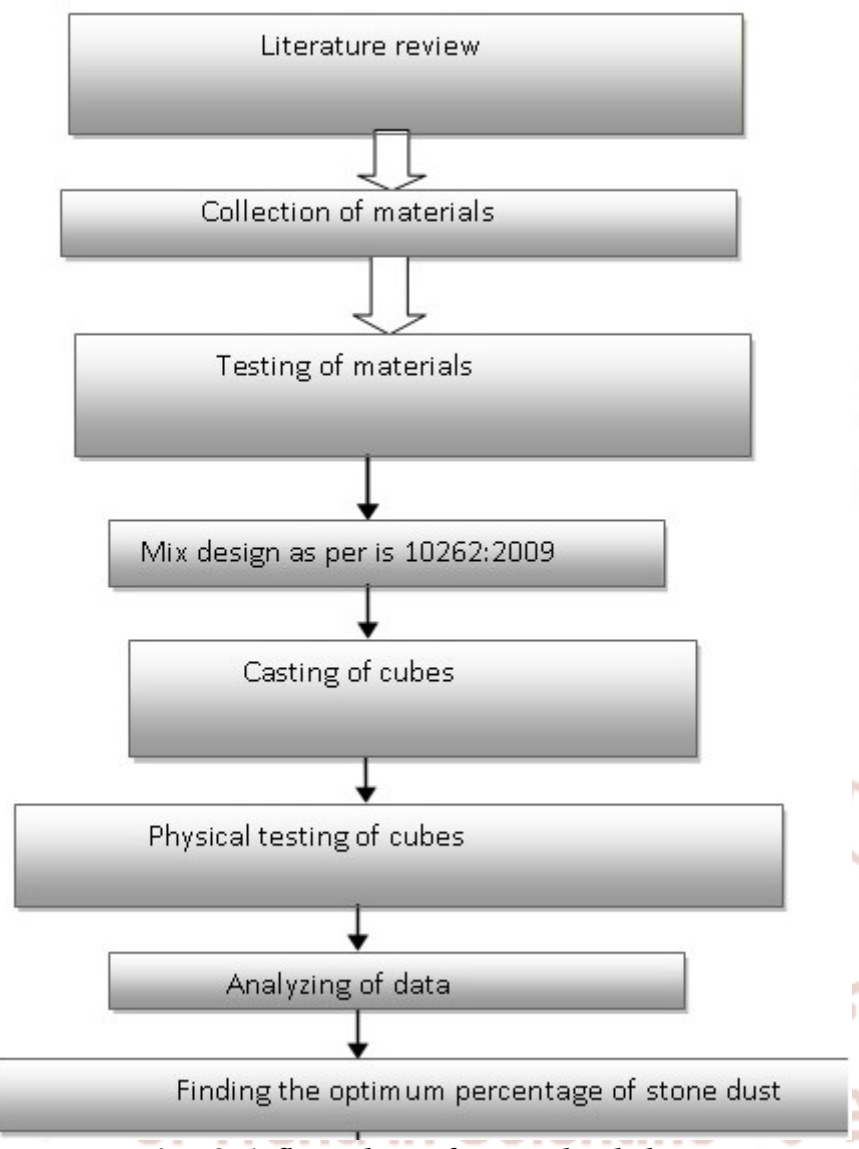

Fig. 3.1 flowchart for methodology

\section{MATERIALS USED AND TESTING PORTLAND CEMENT:}

The cement used was commercially available TCI MAX 43 grade. This cement compiles with the requirements if IS: 8112-2013 for ordinary Portland cement 43 grade.

Following are its requirements

\begin{tabular}{|c|c|c|c|c|}
\hline \multicolumn{2}{|c|}{ PARTICULARS } & TEST RESULTS & \multicolumn{2}{|c|}{$\begin{array}{c}\text { REQUIREMEN } \\
\text { TS OF IS:8112-2013 }\end{array}$} \\
\hline \multicolumn{5}{|c|}{ CHEMICAL REQUIREMENTS } \\
\hline 1. & $\mathrm{CaO}-0.7 \mathrm{SO} 3$ & $0.87 \longrightarrow$ & 0.66 & Min \\
\hline \multicolumn{2}{|r|}{$2.8 \mathrm{SiO} 2+1.2 \mathrm{Al} 2 \mathrm{O} 3+0.65 \mathrm{Fe} 2 \mathrm{O} 3$} & 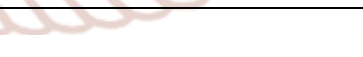 & 1.02 & Max \\
\hline 2. & $\mathrm{~A} 12 \mathrm{O} 3 / \mathrm{Fe} 2 \mathrm{O} 3$ & 1.23 & 0.66 & Min \\
\hline 3. & Insoluble residue (\% by mass) & 2.79 & 4.00 & Max \\
\hline 4. & Magnesia(\% by mass $)$ & 1.36 & 6.00 & Max \\
\hline 5. & Sulphuric Anhydride(\% by mass) & 2.06 & 3.50 & Max \\
\hline 6. & Total loss on ignition(\% by mass) & 2.68 & 5.00 & Max \\
\hline 7. & Total chlorides $(\%$ by mass $)$ & 0.02 & 0.10 & Max \\
\hline \multicolumn{5}{|c|}{ PHYSICAL REQUIREMENTS } \\
\hline 1. & Fineness $\left(\mathrm{m}^{2} / \mathrm{kg}\right)$ & 280 & 225 & Min \\
\hline 2. & Standard consistency $(\%)$ & 27.8 & & \\
\hline 3. & Setting time(minutes) & & & \\
\hline A. & initial & 160 & 30 & Min \\
\hline B. & final & 235 & 600 & Max \\
\hline
\end{tabular}




\begin{tabular}{|l|l|l|l|l|}
\hline \multicolumn{2}{|c|}{ PARTICULARS } & TEST RESULTS & $\begin{array}{c}\text { REQUIREMEN } \\
\text { TS OF IS:8112-2013 }\end{array}$ \\
\hline 4. & Soundness & & & \\
\hline A. & Le-chatliers expansion(mm) & 1.0 & 10.0 & Max \\
\hline B. & Autoclave expansion (\%) & 0.04 & 0.8 & Max \\
\hline 5. & Compressive strength(MPa) & & & \\
\hline A. & $72+/-1$ hr (3 days) & 31.5 & 23 & Min \\
\hline B. & $168+/-2$ hr (7 days) & 41.9 & 33 & Min \\
\hline C. & 672 +/- 4 hr (28 days) & UT & 43 & Min \\
\hline 6. & Performance improver (\%) & & & \\
\hline A. & Limestone & 4.9 & 5.0 & Max \\
\hline B. & fly ash & NA & & \\
\hline C. & granulated slag & NA & & \\
\hline
\end{tabular}

TESTING OF CEMENT 43 GRADE OPC TCI MAX

\begin{tabular}{|c|c|c|c|c|}
\hline (A) CEMENT/ Tests & \multicolumn{3}{|c|}{ CEMENT MAKE: } & OPC-43 \\
\hline Finesse & \multicolumn{4}{|c|}{ JGISIIthy $4 \%$} \\
\hline Consistency & \multicolumn{4}{|c|}{$27 \%$} \\
\hline Initial setting ( Minutes) & \multicolumn{4}{|c|}{130 minutes } \\
\hline Final Setting (Minutes) & \multicolumn{4}{|c|}{210 minutes } \\
\hline Date of cast & \multicolumn{4}{|c|}{\begin{tabular}{l|l|l} 
& $17 / 11 / 2016$
\end{tabular}} \\
\hline $\begin{array}{l}\text { Failure Load (KN) at } 3 \text { days } \\
\text { Dated:20/11/2016 }\end{array}$ & าa140 กa & Jo150 nal & 130 & $\begin{array}{c}\text { Average } \\
140\end{array}$ \\
\hline Strength at 3 days $\left(\mathrm{N} / \mathrm{mm}^{2}\right)$ & \multirow{2}{*}{ encin } & \multirow{2}{*}{ cie 30 ific } & \multirow{2}{*}{26} & Average \\
\hline Dated:20/11/16 & & & & 28 \\
\hline $\begin{array}{c}\text { Failure Load (KN) at } 7 \text { days } \\
\text { Dated:24/11/2016 }\end{array}$ & 170 & 166 & 180 & $\begin{array}{c}\text { Average } \\
172\end{array}$ \\
\hline Strength at 7 days $\left(\mathrm{N} / \mathrm{mm}^{2}\right)$ & & \multirow{2}{*}{\multicolumn{2}{|c|}{\begin{tabular}{|l|l|}
33.20 & 36 \\
\end{tabular}}} & Average \\
\hline Dated: & & & & 34.4 \\
\hline $\begin{array}{c}\text { Failure Load (KN) at } 28 \text { days } \\
\text { Dated: }\end{array}$ & 220 & $215^{\circ}$ & 230 & $\begin{array}{l}\text { Average } \\
274\end{array}$ \\
\hline$\frac{\text { Strength at } 28 \text { days }\left(\mathrm{N} / \mathrm{mm}^{2}\right)}{\text { Dated: } 15 / 12 / 2016}$ & \multicolumn{2}{|l|}{$44=$} & 46 & $\begin{array}{c}\text { Average } \\
44.33\end{array}$ \\
\hline
\end{tabular}

\begin{tabular}{|c|c|}
\hline 7. Bulk Density Compacted & $1416 \mathrm{Kg} / \mathrm{m} 3$ \\
\hline 2. Bulk Density Loose & $1286 \mathrm{Kg} / \mathrm{m} 3$ \\
\hline 3. Bulk Density Average & $1351 \mathrm{Kg} / \mathrm{m} 3$ \\
\hline 4. Specific Gravity & 3.15 \\
\hline
\end{tabular}

COARSE AGGREGATES:

The coarse aggregate used were boulder crushed. Two types of coarse aggregates were used, 20 $\mathrm{mm}$ and $10 \mathrm{~mm}$ nominal size. The specific gravity of $20 \mathrm{~mm} \& 10 \mathrm{~mm}$ were $2.68 \& 2.69$ respectively.

\section{TESTS ON COARSE AGGREGATES:}

Sieve analysis:

The sieve analysis is conducted to determine the particle size distribution in a sample of aggregate which we call gradation. The aggregates used for making concrete are normally of the maximum size $80 \mathrm{~mm}, 40 \mathrm{~mm}, 20 \mathrm{~mm}, 10 \mathrm{~mm}, 4.75 \mathrm{~mm}$, $2.36 \mathrm{~mm}, 600$ micron, 300 micron and 150 
micron. The aggregate fraction from $80 \mathrm{~mm}$ to $4.75 \mathrm{~mm}$ are termed as coarse aggregates and those fraction from $4.75 \mathrm{~mm}$ to 150 micron are termed as fineaggregates.

Grading pattern of a sample of CA or FA is assessed by sieving a sample successively through all the sieves mounted one over the other in order of size, with large sieve at the top. The material retained on each sieve after shaking, represents the fraction of aggregate coarser than the sieve in question and finer than the sieve above. Sieving can be done either manually or mechanically. In the manual operation the sieve is shaken giving movements in all possible directions to give chance to all particles for passing through the sieve. Operation should be continued till such time that almost no particle is passing through.

From the sieve analysis the particle size distribution in a sample of aggregate is found out. In this connection a term called fineness modulus is being used. F.M is a ready index of coarseness or fineness of the material .It is an empirical factor obtained by adding the cumulative percentage of aggregates retained on each of the standard sieves ranging from 80 $\mathrm{mm}$ to 150 micron and dividing this sum by an arbitrary number 100 .The larger the figure, the coarser is the material.

\begin{tabular}{|c|c|c|c|c|}
\hline \multicolumn{5}{|c|}{ AVERAGE INDIVIDUAL GRADATION OF 20mm COARSE AGGREATE } \\
\hline \multirow{3}{*}{ Source } & 20 & As per IS : $2386(\mathrm{~Pa}$ & art -1) & \\
\hline & LAS J & \begin{tabular}{l|l}
$\mathrm{N}$ & \\
\end{tabular} & Proposed Use & concrete \\
\hline & 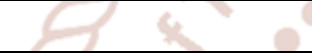 & Sample No-1, $2 \&$ & 30 & \\
\hline $\begin{array}{l}\text { Sieve sizes } \\
(\mathrm{mm})\end{array}$ & Sample-1 & Sample-2 & Sample-3 & $\begin{array}{c}\text { Average } \% \text { of } \\
\text { Passing }\end{array}$ \\
\hline$\underline{10}$ & 100.00 & ernati 9.40 & urnal 100.00 & 9.00 \\
\hline 20 & 93.60 & Tuen 95.20 & 93.20 & 94.00 \\
\hline$\underline{40}$ & 8.90 & 100.00 & $\underline{8.70}$ & 100.00 \\
\hline
\end{tabular}

FINE AGGREGATES: (Stone Dust/ Crushed stone)

The fine aggregate used in all the mixes was stone dust conforming to grading zone -2 after sieve analysis as per IS-383-1970.Its bulk specific gravity at SSD was 2.69 and its fineness modulus ranged from 2.91 to 2.94

Stone dust is a waste material obtained from crusher plants. It has potential to be used as a partial replacement of natural river sand in concrete. Use of stone dust in concrete not only improve the quality of concrete but also conserve the natural river sand for future generations.
Quarry dust can be utilized in concrete mixtures as a good substitute for natural river sand giving strength at $50 \%$ replacement. While using crushed stone dust as fine aggregate in concrete it is found that there is increase in compressive, flexural and tensile strength of concrete

\section{TESTS ON FINE AGGREGATES:}

Sieve analysis:

The sieve analysis of fine aggregates is conducted in the same way as for coarse aggregates except that the sieves finer than 4.75 $\mathrm{mm}$ are used. 
International Journal of Trend in Scientific Research and Development (IJTSRD) ISSN: 2456-6470

Following are the results of sieve analysis:

\begin{tabular}{|c|c|c|c|c|c|c|c|c|}
\hline TESTING OF (F.A./ stonedust) & \multicolumn{3}{|c|}{ WEIGHT OF SAMPLE=2,000 GRAMS } \\
\hline $\begin{array}{c}\text { Sieve } \\
\text { Designation }\end{array}$ & $\begin{array}{c}\text { Weight } \\
\text { Retained }\end{array}$ & $\%$ & Cumulative & $\begin{array}{c}\% \\
\text { Passing }\end{array}$ & \multicolumn{3}{|c|}{ Prescribed Limits meets zone- } \\
\hline & & & & & ZONE-I & $\begin{array}{c}\text { ZONE- } \\
\text { II }\end{array}$ & $\begin{array}{c}\text { ZONE- } \\
\text { III }\end{array}$ & $\begin{array}{c}\text { ZONE- } \\
\text { IV }\end{array}$ \\
\hline $10 \mathrm{~mm}$ & 0 & 0 & 0 & 100 & 100 & 100 & 100 & 100 \\
\hline $4.75 \mathrm{~mm}$ & 0 & 0 & 0 & 100 & $90-100$ & $90-100$ & $90-100$ & $95-100$ \\
\hline $2.36 \mathrm{~mm}$ & 104 & 5.2 & 5.2 & 94.8 & $60-95$ & $75-100$ & $85-100$ & $95-100$ \\
\hline $1.18 \mathrm{~mm}$ & 866 & 43.3 & 48.5 & 51.5 & $30-70$ & $55-90$ & $75-100$ & $90-100$ \\
\hline $0.60 \mathrm{~mm}$ & 702 & 35.1 & 83.6 & 16.4 & $15-34$ & $35-59$ & $60-79$ & $80-100$ \\
\hline $0.30 \mathrm{~mm}$ & 168 & 8.4 & 92 & 8 & $5-20$ & $8-30$ & $12-40$ & $15-50$ \\
\hline $0.15 \mathrm{~mm}$ & 100 & 0.5 & 95.5 & 3 & $0-10$ & $0-10$ & $0-10$ & $0-15$ \\
\hline$-0.15 \mathrm{~mm}$ & 60 & 3 & 95.5 & & Zone I & & & \\
\hline
\end{tabular}

\section{GRADATIONOF STONE DUST}

Weight of sample $=2000 \mathrm{gms}$

\begin{tabular}{|c|c|c|c|c|c|c|c|}
\hline $\begin{array}{c}\text { IS Sieve } \\
\text { Size in mm }\end{array}$ & $\begin{array}{c}\text { \% Passing } \\
\text { (Sample-1) }\end{array}$ & $\begin{array}{c}\text { \% Passing } \\
\text { (Sample-2) }\end{array}$ & $\begin{array}{c}\text { \% Passing } \\
\text { (Sample-3) }\end{array}$ & $\begin{array}{c}\text { Avg \% of } \\
\text { Passing }\end{array}$ & \multicolumn{2}{|c|}{$\begin{array}{c}\text { Specification Limits As IS 383 } \\
\text {-1970 Table No-04 }\end{array}$} \\
\hline 10 & 100 & 100 & 100 & 100.0 & 100 & 100 & 100 \\
\hline 4.75 & 100 & 93.2 & 94.1 & 93.5 & $90-100$ & $90-100$ & $90-100$ \\
\hline 2.36 & 94.8 & 84.6 & 84.3 & 84.6 & $60-95$ & $75-100$ & $85-100$ \\
\hline 1.18 & 51.5 & 53.1 & 54.2 & 52.93 & $30-70$ & $55-90$ & $75-100$ \\
\hline 0.600 & 16.4 & 16.8 & 17.6 & 16.9 & $15-34$ & $35-59$ & $60-79$ \\
\hline 0.300 & 8 & 8.5 & 8.6 & 8.36 & $5-20$ & $8-30$ & $12-40$ \\
\hline 0.150 & 3 & 3.3 & 2.9 & 3.06 & $0-10$ & $0-10$ & $0-10$ \\
\hline & & & & & Zone -I & & \\
\hline
\end{tabular}

\section{WATER:}

Water is an important ingredient of concrete as it actively participates in the chemical reaction with cement. Since it helps to form the strength giving cement gel, the quantity and quality of water is required to be looked into very carefully.

\section{SUPERPLASTICIZER:}

The super plasticizer used was AURAMIX 200 which is the advanced low viscosity high performance super plasticizer based on polycarboxylic ether.

\section{Uses:}

Auramix 200 is a high performance retarding super plasticizer intended for applications where retarding and long workability retention are required, and it has been developed for use in:

$>$ Mass raft foundation

$>$ Pumped concrete

$>$ Concrete requiring long workability retention

$>$ High performance concrete

\section{Advantages:}

Increased retardation controls the heat of hydration and yields high ultimate strength

$>$ Higher E modulus

Improved adhesion to reinforcing and prestressing steel

$>$ Better resistance tocarbonation

$>$ Lower permeability

Better resistance to aggressive atmospheric conditions

$>$ Reduced shrinkage andcreep

$>$ Increased durability

\section{DESCRIPTION:}

Auramix 200 is a unique combination of the latest generation super plasticizers based on a polycarboxylic ether polymer with long lateral chains. This greatly improves cement dispersion. At the start of the mixing process an electrostatic dispersion occurs but the cement particles capacity to separate and disperse. 
This mechanism considerably reduces the water demand in flow able concrete.

Auramix200 combines the properties of water reduction and workability retention. It allows the production of high performance concrete and/or concrete with high workability.

Auramix 200 is a strong super plasticizer allowing production of consistent concrete properties around the required dosage.

\section{TECHNICAL SUPPORT:}

Fosroc provides a technical advisory service for on-site assistance and advice on mix design, admixture selection, evaluation trials and dispensing equipment.

\section{Properties:}

$>$ Appearance : light yellow coloured liquid

$>\mathrm{PH}$ : minimum 6.0

>Volumetric mass@200 C:1.105kg/litre

$>$ Chloride content : nil to IS:456

$>$ Alkali content : typically less than $1.5 \mathrm{~g}$ $\mathrm{Na} 2 \mathrm{O}$ equivalent/litre Of admixture

\section{Dosage:}

The optimum dosage of Aura mix 200 to meet specific requirements should always $/$ be determined by trials sing the materials and conditions that will be experienced in use. The normal dosage range is between 0.5 to 3.0 litres $/ 100 \mathrm{~kg}$ of cementitious material.

\section{Effects of over dosing:}

Over dosage may cause delay in the setting time and segregation.

\section{Storage:}

Auramix 200 has a minimum self-life of 24 months provided the temperature is kept within the range of $2^{0} \mathrm{C}$ to $50^{0} \mathrm{C}$.

\section{MIXING PROCEDURE:}

To get better efficiency, the following sequence is adopted:
Firstly, about half the quantity of coarse aggregate is placed in the drum over which about half the quantity of fine aggregate is poured. On that the full quantity of cement over which the remaining portion of coarse aggregate and fine aggregate is deposited in sequence. This prevents spilling of cement while discharging into the drum and also this prevents the blowing away of cement in windy weather.

In lab, we have generally the drum having capacity of generally 40 Litres, in which materials required for casting of nine cubes is poured

\section{DESIGN CALCULATIONS}

\section{NORMAL CONTROL MIX}

DESIGN MIX OF CONCRETENORMAL (T1N M40)

\subsection{SPECIFICATION FOLLOWED}

A. Plain and reinforced concrete code of practice ( $4^{\text {th }}$ Revision) IS $456-2000$.

B. Hand book on concrete mix (Based on Indian Standard) SP 23-1982.

C. Recommended guidelines for concrete mix design. IS $10262-2009$

D. Specification for coarse and fine aggregate from natural sources for concrete IS $383-$ 1970.

E. Code for OPC 43 grade IS: 8112-2013

F. Code for Admixtures uses IS: 9103:1944

G. Project Technical Specification

\section{DESIGN STIPULATIONS}

A. Grade designation

B. Type of cement

C. Maximum size of aggregate

D. Degree of workability (slump value)

E. Degree ofquality control

F. Type of exposure $=$ Moderate

G. Minimum cement content $=320 \mathrm{Kg} / \mathrm{m}^{3}$

H. Maximum water-cement ratio $=0.45$ 
International Journal of Trend in Scientific Research and Development (IJTSRD) ISSN: 2456-6470

SOURCES OF MATERIALS AND TEST DATA

\begin{tabular}{|c|c|c|c|c|c|}
\hline S. No & Name ofMaterials & Source & $\begin{array}{c}\text { Specific } \\
\text { Gravity }\end{array}$ & $\begin{array}{c}\text { Water } \\
\text { Absorption (\%) }\end{array}$ & $\begin{array}{c}\text { Free surface } \\
\text { water (\%) }\end{array}$ \\
\hline 1 & $\begin{array}{c}\text { Cement (OPC 43) } \\
\text { Brand-TCIMAX }\end{array}$ & 3.15 & - & 0.2 \\
\hline 2 & $\begin{array}{c}\text { Coarse aggregate } \\
(20 . \mathrm{mm})\end{array}$ & LASJAN PAMPORE & 2.68 & 0.50 & 0.1 \\
\hline 3 & $\begin{array}{c}\text { Coarse aggregate } \\
(10 . \mathrm{mm})\end{array}$ & LASJAN PAMPORE & 2.68 & 0.5 & 1.5 \\
\hline 4 & $\begin{array}{c}\text { Fine aggregate } \\
(\text { Stone dust -Zone I })\end{array}$ & LASJAN PAMPORE & 2.69 & 0.6 & - \\
\hline 5 & Water & Bore well & 1 & - & \\
\hline
\end{tabular}

TARGET MEAN STRENGTH OFCONCRETE

As per IS -10262 -2009 target mean strength of concrete is given by $\mathrm{fM}=\mathrm{fCK}+1.65 \partial$ where

$\partial$ is standard deviation of samples of cubes strength and $\mathrm{fCK}$ is the characteristic mean strength of concrete which means $95 \%$ of cube strength will fall under this strength now in our case

Target mean strength $=40+1.65 \times 5=48.25 \mathrm{MPa}$

\section{SELECTION OF WATER CEMENT RATIO}

From figure - 1 (IS 10262) and Figure 46 (SP 23) the free water cement required for the target mean strength of $48.25 \mathrm{~N} / \mathrm{mm} 2$ is 0.37 but as we had compare properties of concrete using admixture we reduced water cement ratio for control mix 0.40 From Technical specification MORTH Table no 1700-3(A) maximum water cement ratio is 0.45 for Normal exposure. Therefore it is decided that water cement ratio for M40 grade concrete shall be 0.37

\section{SELECTION OF STONE DUST CONTENT}

The dry mix of coarse and fine aggregate are mixed at a ratio $60 \%$ and $40 \%$ and checked for all in aggregate as per Table-4 (IS 383). It is found that the above ratio is satisfactory for $20 \mathrm{~mm}$ graded aggregate. Hence the percent of fine aggregate is considered as $40 \%$.

\section{DETERMINATION OF WATER CONTENT\& CEMENT}

Water cement ratio $=0.37$

For $20 \mathrm{~mm}$, Maximum water $=186 \mathrm{~L}$ (table 5 IS: 10262-2009)

Add 6\% water for additional slump (3\% increase for every $25 \mathrm{~mm}$ slump over)

so, required water $=186+6 \%$ of 186

$$
=197.16 \mathrm{~L}
$$

As $\mathrm{w} / \mathrm{c}=0.37 \& \mathrm{w}=197.16$

So, cement $=\underline{197.16}$

0.37

$=532.86 \mathrm{Kg}$

As minimum cement $=360 \mathrm{Kg} / \mathrm{m}^{3}$ so,

Adopt cement $=532.86 \mathrm{Kg} / \mathrm{m}^{3}$

\section{DETERMINATIONOF COARSE AND} FINE AGGREGATE CONTENT

From Table 3 volume of coarse aggregate corresponding to $20 \mathrm{~mm}$ size aggregate and fine aggregate (Zone I)

For water-cement ratio of $0.50=0.60$.

In the present case water-cement ratio is 0.37 . Therefore, volume of coarse aggregate is required to be increased to decrease the fine aggregate content. As the water-cement ratio is lower by 0.10 the proportion of volume of coarse aggregate is increased by 0.02 (at the rate of -/+ 0.01 for every \pm 0.05 change in water-cement ratio).

Therefore, corrected proportion of volume of coarse aggregate for the water-cement ratio of $0.37=0.60$.

Therefore, volume of coarse aggregate $=0.60$

So, $(\underline{0.01}) \times 0.13=0.026$

$$
0.05
$$

Volume of C.A $\quad=0.626$

Volume ofFine aggregate $=1-0.626$

$=0.374$

Calculations for DESIGN MIX OF CONCRETE Trial V (M 40 with Auromix 200)

$>$ Same specifications as followed in $\mathrm{T} 1 \mathrm{~N}$

$>$ Dosage $=1.6 \%$

> 20mm: $10 \mathrm{~mm}=40 \%: 60 \%$ 
$\mathrm{w} / \mathrm{c}=0.33$

Calculation follows as under the given steps:

\subsection{TARGET MEAN STRENGTH OF CONCRE:}

As per IS -10262 -2009 target mean strength of concrete is given by $\mathrm{fM}=\mathrm{fCK}+1.65 \partial$ where

$\partial$ is standard deviation of samples of cubes strength and fCK is the characteristic mean strength of concrete which means $95 \%$ of cube strength will fall under this strength now in our case

Target mean strength $=40+1.65 \times 5=48.25 \mathrm{MPa}$

Calculation OE WATER CEMENTRATIO:

From table 2 of IS 10262-2009,

$$
\mathrm{W}=186 \mathrm{~L}
$$

Since As per IS 10262-2009,

Water reducing admixtures usually decrease water content by 5-20 percent. Clause 4.2)

$\therefore \quad \mathrm{W}=186(1-19 \%)=150.66 \mathrm{~L}$

As $\mathrm{w} / \mathrm{c}=0.33$

$\therefore \quad c=\underline{150.66}=457 \mathrm{Kg} / \mathrm{m}^{3}$

$$
0.33
$$

\section{DETERMINATION OF COARSE AND FINE}

\section{AGGREGATE CONTENT}

From Table 3 volume of coarse aggregate corresponding to $20 \mathrm{~mm}$ size aggregate and fine aggregate (Zone I)

For water-cement ratio of $0.50=0.60$.

In the present case water-cement ratio is 0.33 . Therefore, volume of coarse aggregate is required to be increased to decrease the fine aggregate content. As the water-cement ratio is lower by 0.17 the proportion of volume of coarse aggregate is increased by 0.02 (at the rate of $-/+$ 0.01 for every \pm 0.05 change in water-cement ratio).

Therefore, corrected proportion of volume of coarse aggregate for the water-cement ratio of $0.40=0.62$.

Therefore, volume of coarse aggregate $=0.60$

So, $\underline{0.01} \times 0.17=0.034$

$$
0.05
$$

Volume of C.A $=0.634$
Since the concrete is pumped, reduction of CA by $8 \%$

$\therefore$ Volume ofCA $=0.634(1-0.06)=0.596 \mathrm{~m}^{3}$

Volume of Fine aggregate $\quad=1-0.596$

$=0.404 \mathrm{~m}^{3}$

\section{CALCULATIONS OF MIX PROPORTIONS;}

A. Volume of concrete $=1 \mathrm{~m}^{3}$

Volume of

Cement $=$ Mass of cement $\quad$ x 1 Specific gravity of cement 1000

$=457 \times 1$

3.151000

$=0.145 \mathrm{~m}^{3}$

B. Volume of

water $=$ Mass of water $\quad$ x 1 Specific gravity of water $\quad 1000$ $=150.66 \times 1$ $=0.150 \mathrm{~m}^{3}$

C. Volume of Auromix 200

(Superplasticizer)(@1.6percent

By mass of cementitiousmaterial)

$$
=1.6 \% \times \frac{457}{1.07 \times 10000}
$$$$
=0068 \mathrm{~m}^{3}
$$

E. Volume of all in aggregates

$$
=1-(0.145+0.150+0.0068)=0.6982 \mathrm{~m}^{3}
$$

F. Mass of coarse aggregates $=\mathrm{d} \times$ Volume of coarse aggregate $x$ Specific gravity of coarse aggregate $\mathrm{x}$ I 000

$=0.6982 \times 0.596 \times 2.68 \times 1000$

$=1115.22 \mathrm{Kg} / \mathrm{m}^{3}$

G. Mass of fine aggregate

$=\mathrm{d} \times$ volume of fine aggregate $\mathrm{x}$ specific gravity of fine

Aggregate $\mathrm{x} 1000=0.6982 \times 0.404 \times 2.69 \times 1000$

$$
=758.78 \mathrm{Kg} / \mathrm{m}^{3}
$$

H. Mass of Auromix $200=0.0068 \times 1.07 \times 1000$

$$
=7.30 \mathrm{Kg} / \mathrm{m}^{3}
$$


International Journal of Trend in Scientific Research and Development (IJTSRD) ISSN: 2456-6470

\section{WATER CORRECTIONS}

\section{WATER ABSORPTION}

C. $\mathrm{CA}=0.5 \%=0.5 \times 1115.22=5.60 \mathrm{~L}$ 100

D. $F A=0.6 \%=0.6 \times 758.78=4.55 \mathrm{~L}$ 100

Total quantity $\quad=10.15 \mathrm{~L}$

\section{FREE MOISTURE}

A. $\mathrm{FA}=1.5 \%=1.5 \times 758.78=11.38 \mathrm{~L}$ 100

B. CA

$20 \mathrm{~mm}$ aggregates $=40 \times 1115.22 \times 0.2 \%$ 100 $=0.892 \mathrm{Kg}$

$10 \mathrm{~mm}$ aggregates $=60 \% \times 1115.22 \times 0.1 \%$ $=0.67 \mathrm{Kg}$ Total quantity$$
=12.942 \mathrm{~kg}
$$

$\therefore \quad$ Actual amount of water to be used$=150+10.15-12.942=147.21 \mathrm{~L}$ Actual F.A $=758.78-4.55+11.38=765.61 \mathrm{Kg} / \mathrm{m}^{3}$ Actual CA

$=1115.22-5.60+0.892+.67$

$=1111.18 \mathrm{Kg} / \mathrm{m}^{3}$

Proportions of materials at the site:

Cement $457 \mathrm{Kg} / \mathrm{m}^{3}$

Water

C.A

F. A

Auromix 200
$147.21 \mathrm{Kg} / \mathrm{m}^{3}$

$1111.18 \mathrm{Kg} / \mathrm{m}^{3}$

$765.61 \mathrm{Kg} /{ }^{3}$

$7.30 \mathrm{Kg} / \mathrm{m}^{3}$

\section{DETAIL OF CONCRETETRIAL} NORMAL TRIALS WITHOUT ADMIXTURE

$\mathrm{T} 1 \mathrm{~N} \& \mathrm{~T} 2 \mathrm{~N}$

\begin{tabular}{|c|c|c|c|c|}
\hline $\begin{array}{l}\text { S. } \\
\text { No. }\end{array}$ & $\begin{array}{c}\text { Description of Trial } \\
\text { Mix }\end{array}$ & Unit & Trial Mix NoT1N & Trial Mix NoT2N \\
\hline 01 & $\begin{array}{ccc}\text { Grade } & \text { of } & \text { Concrete } \\
\text { Mix } & \end{array}$ & MP & nd $\mathrm{M}-40 \mathrm{PSC}$ & $\mathrm{M}-40 \mathrm{PSC}$ \\
\hline 02 & Target Mean Strength & $\mathrm{MPa}$ & 48.25 & 48.25 \\
\hline 03 & Grade of Cement & & 43 Grade TCI MAX & 43 Grade TCI MAX \\
\hline 04 & $\begin{array}{c}\text { Name \& Source } \\
\text { of Aggregate }\end{array}$ & & $\begin{array}{l}\text { CA:LAS JAN Quarry, } \\
\text { FA: LAS JAN }\end{array}$ & CA:LASJAN FA:LASJAN \\
\hline 05 & Water-Cement Ratio & & $2=0.35=$ & 0.37 \\
\hline 06 & Date ofCasting & & N. $30-11-2016$ & $30-11-2016$ \\
\hline 07 & $20 \mathrm{~mm}: 10 \mathrm{~mm}$ & & $40 \%: 60 \%$ & $40 \%: 60 \%$ \\
\hline 08 & Specific Gravity & & $\begin{array}{r}\text { CA: } 2.68 \\
\text { FA: } 2.69 \\
\end{array}$ & $\begin{array}{l}\text { CA:2.68 } \\
\text { FA:2.69 }\end{array}$ \\
\hline 09 & Water absorption & & $\begin{array}{l}\text { CA: } 0.5 \% \\
\text { FA: } 0.6 \% \\
\end{array}$ & $\begin{array}{l}\text { CA: } 0.5 \% \\
\text { FA: } 0.6 \% \\
\end{array}$ \\
\hline \multirow{6}{*}{10} & $\begin{array}{c}\text { Trial Mix FOR } 9 \\
\text { CUBES Volume of } 9 \\
\text { cubes }=9 \times 0.15 \times .15 \times .15\end{array}$ & & $\Delta S$ & \\
\hline & a) Cement & $\mathrm{Kg}$ & 17.11 & 16.18 \\
\hline & \begin{tabular}{|l|} 
b) Water \\
\end{tabular} & $\mathrm{Kg}$ & 5.94 & 5.930 \\
\hline & $\begin{array}{lcc}\text { c) } & \text { Coarse } & \text { Agg.-20 } \\
\mathrm{mm}\end{array}$ & $\mathrm{Kg}$ & 12.76 & 12.87 \\
\hline & $\begin{array}{lll}\text { d) } & \text { Coarse } & \text { Agg.-10 } \\
\mathrm{mm} & \\
\end{array}$ & $\mathrm{Kg}$ & 19.13 & 19.32 \\
\hline & e) Fine Agg.- stone dust & $\mathrm{Kg}$ & 19.03 & 19.55 \\
\hline 11 & Compaction Factor & & $\begin{array}{l}\text { Initial:0.61 } \\
\text { Final:0.75 }\end{array}$ & $\begin{array}{l}\text { Initial: } 0.54 \\
\text { Final:0.71 }\end{array}$ \\
\hline
\end{tabular}


International Journal of Trend in Scientific Research and Development (IJTSRD) ISSN: 2456-6470

\begin{tabular}{|c|c|c|c|c|c|c|}
\hline $\begin{array}{l}\text { S. } \\
\text { No. }\end{array}$ & $\begin{array}{l}\text { Description of Trial } \\
\text { Mix }\end{array}$ & Unit & Trial Mix NoT1N & \multicolumn{3}{|c|}{ Trial Mix NoT2N } \\
\hline \multirow{3}{*}{12} & Slump Data: & & & & & \\
\hline & a) initial & $\mathrm{Mm}$ & 30 & \multicolumn{3}{|c|}{27} \\
\hline & b) after 30 minutes & $\mathrm{Mm}$ & 10 & \multicolumn{3}{|c|}{9} \\
\hline \multirow{5}{*}{13} & Compressive Strength & & & & & \\
\hline & \multirow[t]{2}{*}{ a) 7-days strength } & $\begin{array}{l}\text { Date of } \\
\text { Testing }\end{array}$ & $7-12-2016$ & \multicolumn{3}{|c|}{$7-12-2016$} \\
\hline & & Mpa & Average $=30.07$ & \multicolumn{3}{|c|}{ Average $=29$} \\
\hline & \multirow[t]{2}{*}{ b) 28 - days strength } & $\begin{array}{l}\text { Date of } \\
\text { Testing }\end{array}$ & $28-12-2016$ & \multicolumn{3}{|c|}{$28-12-2016$} \\
\hline & & Mpa & 40 & 4240.5 & \begin{tabular}{l|l}
40 & 40.5 \\
\end{tabular} & 41 \\
\hline 14 & $\begin{array}{l}\text { Avg. Compressive } \\
\text { Strength }\end{array}$ & Mpa & 40.83 & \multicolumn{3}{|c|}{40.5} \\
\hline
\end{tabular}

TRIALS WITH ADMIXTURE (1-8)\

T1 \& T2 (with $19 \%$ waterreduction)

\begin{tabular}{|c|c|c|c|c|}
\hline $\begin{array}{l}\text { S. } \\
\text { No. }\end{array}$ & Description of Trial Mix & Unit & Trial Mix No. T1 & Trial Mix No.T2 \\
\hline 01 & Grade of Concrete Mix & $\mathrm{MPa}$ & $\mathrm{M}-40$ & $M-40$ \\
\hline 02 & Target Mean Strength & $\mathrm{MPa}$ & $4 \longdiv { 4 8 . 2 5 }$ & 48.25 \\
\hline 03 & Grade of Cement & 10 & $\begin{array}{l}43 \text { Grade TCI MAX OPC } \\
\text { Cement }\end{array}$ & $\begin{array}{l}43 \text { GRADE TCI MAX } \\
\text { OPC Cement }\end{array}$ \\
\hline 04 & $\begin{array}{l}\text { Name \& Source of } \\
\text { Aggregate }\end{array}$ & etrial & $\begin{array}{l}\text { CA LAS JAN Quarry, FA: } \\
\text { LASJ JAN }\end{array}$ & $\begin{array}{l}\text { CA LAS JAN FA: } \\
\text { LASJAN }\end{array}$ \\
\hline 05 & Water-Cement Ratio & & 0.35 & 0.35 \\
\hline 06 & 20mm:10mm & Res & arch $60 \%: 40 \%$ & $30 \%: 70 \%$ \\
\hline 07 & Date of Casting & & $21-11-2016$ & $22-11-2016$ \\
\hline 08 & Specific gravity & & $\begin{array}{l}\text { CA:2.68 } \\
\text { FA: } 2.69\end{array}$ & $\begin{array}{l}\text { CA:2.68 } \\
\text { FA:2.69 }\end{array}$ \\
\hline 09 & Water absorption & & $\begin{array}{c}2456 \text { - CA: } 0.5 \% \\
\text { FA: } 0.6 \% \\
\end{array}$ & $\begin{array}{l}\text { CA: } 0.5 \% \\
\text { FA: } 0.6 \% \\
\end{array}$ \\
\hline \multirow{8}{*}{10} & $\begin{array}{c}\text { Trial Mix Proportions ( for } \mathrm{s} \\
\text { cubes ) }\end{array}$ & & 2.000 & \\
\hline & \begin{tabular}{|l|} 
a) Cement \\
\end{tabular} & $\mathrm{Kg}$ & -13.09 & 13.09 \\
\hline & b) Water & $\mathrm{Kg}$ & 4.50 & 4.50 \\
\hline & c) Coarse Agg.-20 mm & $\mathrm{Kg}$ & $\begin{array}{l}13.50 \\
\end{array}$ & 9.87 \\
\hline & d) Coarse Agg. $-10 \mathrm{~mm}$ & $\mathrm{Kg}$ & 20.20 & 23.03 \\
\hline & e) Fine Agg.- & $\mathrm{Kg}$ & 23.60 & 24.30 \\
\hline & g) Admixture Brand & & AURAMIX 200 & AURAMIX 200 \\
\hline & h) Admixture Quantity & $\mathrm{Kg}$ & $1.6 \%$ & $1.6 \%$ \\
\hline \multirow{3}{*}{11} & Slump Data : & & & \\
\hline & a) initial & $\mathrm{Mm}$ & 190 & 200 \\
\hline & b) after 30 minutes & $\mathrm{mm}$ & 145 & 125 \\
\hline \multirow{5}{*}{12} & Compressive Strength & & & \\
\hline & a) 7- days strength & $\begin{array}{l}\text { Date of } \\
\text { Testing }\end{array}$ & $28-11-206$ & $29-11-2016$ \\
\hline & & $\mathrm{MPa}$ & Average $=29.33$ & Average $=44.33$ \\
\hline & \multirow[t]{2}{*}{ b) 28 - daysstrength } & $\begin{array}{l}\text { Date of } \\
\text { Testing }\end{array}$ & $19-12-2016$ & $20-12-2016$ \\
\hline & & $\mathrm{MPa}$ & $40 \mid 42.22$ & \begin{tabular}{|l|l|}
57.78 & 57.33 \\
\end{tabular} \\
\hline
\end{tabular}


International Journal of Trend in Scientific Research and Development (IJTSRD) ISSN: 2456-6470

\begin{tabular}{|c|c|c|c|c|}
\hline $\begin{array}{c}\text { S. } \\
\text { No. }\end{array}$ & Description of Trial Mix & Unit & Trial Mix No. T1 & Trial Mix No.T2 \\
\hline 13 & Avg. Compressive Strength & $\mathrm{MPa}$ & 42.81 & 58.81 \\
\hline 14 & Compaction Factor & & Initial $: 0.963$ & Initial:0.953 \\
& & & Final: 0.980 & Final:0.985 \\
\hline
\end{tabular}

T3 \& T4 ( With 19\% water reduction)

\begin{tabular}{|c|c|c|c|c|}
\hline $\begin{array}{l}\text { S. } \\
\text { No. }\end{array}$ & Description of Trial Mix & Unit & Trial Mix No. T3 & Trial Mix No.T4 \\
\hline 01 & Grade of Concrete Mix & $\mathrm{MPa}$ & $M-40$ & $M-40$ \\
\hline 02 & Target Mean Strength & $\mathrm{MPa}$ & 48.25 & 48.25 \\
\hline 03 & Grade of Cement & & $\begin{array}{c}43 \text { Grade TCI MAX OPC } \\
\text { Cement }\end{array}$ & $\begin{array}{c}43 \text { GRADE TCI MAX } \\
\text { OPC Cement }\end{array}$ \\
\hline 04 & $\begin{array}{c}\text { Name \& Source of } \\
\text { Aggregate }\end{array}$ & & $\begin{array}{c}\text { CA LASJ JAN Quarry, FA: } \\
\text { LASJ AN }\end{array}$ & $\begin{array}{l}\text { CA LASJAN FA: } \\
\text { LASJAN }\end{array}$ \\
\hline 05 & Water-Cement Ratio & 3 & 0.35 & 0.35 \\
\hline 07 & $20 \mathrm{~mm}: 10 \mathrm{~mm}$ & C & cilen $35 \%: 65 \%$ & $35 \%: 65 \%$ \\
\hline 08 & Specific gravity & & $\begin{array}{l}\text { CA:2.68 } \\
\text { FA:2.69 }\end{array}$ & $\begin{array}{l}\text { CA:2.68 } \\
\text { FA:2.69 }\end{array}$ \\
\hline 09 & Water absorption & & $\begin{array}{l}\text { CA: } 0.5 \% \\
\text { FA: } 0.6 \%\end{array}$ & $\begin{array}{l}\text { CA: } 0.5 \% \\
\text { FA: } 0.6 \%\end{array}$ \\
\hline 10 & Date of Casting & 10 & $23-11-2016$ & $23-11-2016$ \\
\hline \multirow{8}{*}{11} & $\begin{array}{c}\text { Trial Mix Proportions (for } \\
9 \text { cubes ) }\end{array}$ & el & Journa & \\
\hline & a) Cement & $\mathrm{Kg}$ & $\mathrm{l}$ in coil 13.09 & 13.09 \\
\hline & b) Water & $\mathrm{Kg}$ & 4.48 & 4.50 \\
\hline & c) Coarse Agg.-20 mm & $\mathrm{Kg}$ & earch 11.51 & 11.62 \\
\hline & d) Coarse Agg. $-10 \mathrm{~mm}$ & $\mathrm{Kg}$ & $\begin{array}{r}21.39 \\
\end{array}$ & 21.58 \\
\hline & e) Fine Agg.- & $\mathrm{Kg}$ & 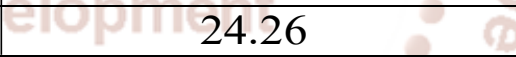 & 24.47 \\
\hline & g) Admixture Brand & & AURAMIX 200 & AURAMIX 200 \\
\hline & h) Admixture Dosage & SS & $2456=641.6 \%$ & $1.7 \%$ \\
\hline \multirow{3}{*}{12} & Slump Data : & & & \\
\hline & a) initial & $\mathrm{mm}$ & 210 & 210 \\
\hline & b) after 30 minutes & $\mathrm{mm}$ & 51 & 75 \\
\hline \multirow{5}{*}{13} & Compressive Strength & & 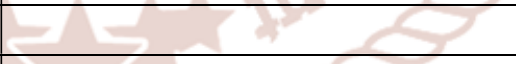 & \\
\hline & \multirow[t]{2}{*}{ a) 7- days strength } & $\begin{array}{l}\text { Date of } \\
\text { Testing }\end{array}$ & $30-11-206$ & $1-12-2016$ \\
\hline & & $\mathrm{MPa}$ & Average $=33.77$ & Average $=41.06$ \\
\hline & \multirow[t]{2}{*}{ b) 28-days strength } & $\begin{array}{l}\text { Date of } \\
\text { Testing }\end{array}$ & $21-12-2016$ & $22-12-2016$ \\
\hline & & $\mathrm{MPa}$ & \begin{tabular}{l|l|l|}
49.8 & 54. & 48.9 \\
\end{tabular} & 41.3 \\
\hline 14 & Avg. Compressive Strength & $\mathrm{MPa}$ & 51 & 38.66 \\
\hline 15 & Compaction factor & & $\begin{array}{cc}\text { Initial: } & 0.954 \\
\text { Final: } & 0.968\end{array}$ & $\begin{array}{cc}\text { Initial: } & 0.984 \\
\text { Final: } & 0.990\end{array}$ \\
\hline
\end{tabular}

T5 \& T6

\begin{tabular}{|c|c|c|c|c|}
\hline $\begin{array}{c}\text { S. } \\
\text { No. }\end{array}$ & Description of Trial Mix & Unit & Trial Mix No. T5 & Trial Mix No.T6 \\
\hline 01 & Grade of Concrete Mix & $\mathrm{MPa}$ & $\mathrm{M}-40$ & $\mathrm{M}-40$ \\
\hline 02 & Target Mean Strength & $\mathrm{MPa}$ & 48.25 & 48.25 \\
\hline
\end{tabular}


International Journal of Trend in Scientific Research and Development (IJTSRD) ISSN: 2456-6470

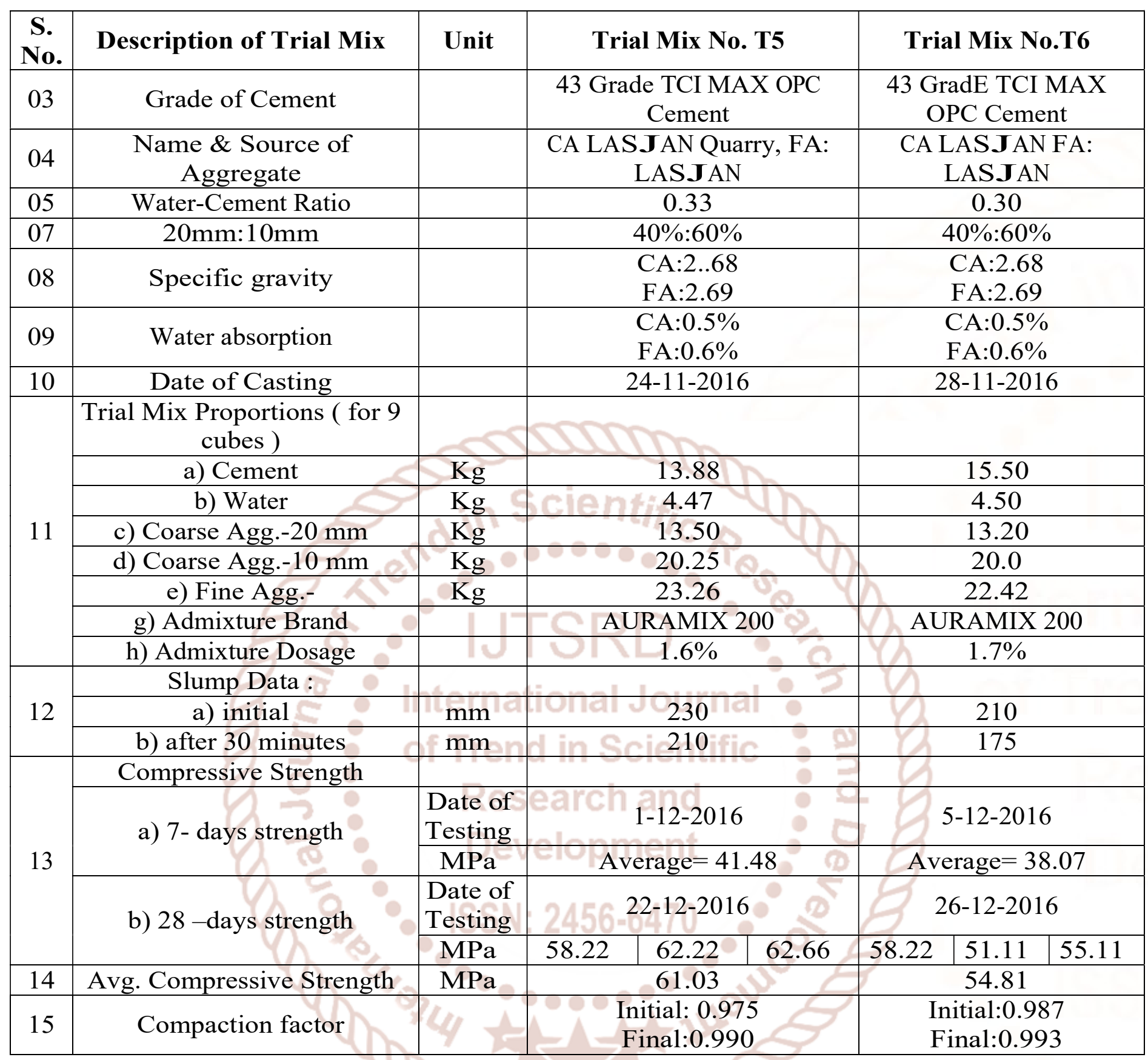

T7 \& T8

\begin{tabular}{|c|c|c|c|c|}
\hline $\begin{array}{l}\text { S. } \\
\text { No. }\end{array}$ & Description of Trial Mix & Unit & Trial Mix No. T 7 & Trial Mix No.T8 \\
\hline 01 & Grade of Concrete Mix & $\mathrm{MPa}$ & $M-40$ & $M-40$ \\
\hline 02 & Target Mean Strength & $\mathrm{MPa}$ & 48.25 & 48.25 \\
\hline 03 & Grade of Cement & & $\begin{array}{c}43 \text { Grade TCI MAX OPC } \\
\text { Cement }\end{array}$ & $\begin{array}{c}43 \text { GradE TCI MAX OPC } \\
\text { Cement }\end{array}$ \\
\hline 04 & Name \& Source of Aggregate & & $\begin{array}{c}\text { CA LASJAN Quarry, FA: } \\
\text { LASJAN }\end{array}$ & $\begin{array}{l}\text { CA LASJAN FA: } \\
\text { LASJAN }\end{array}$ \\
\hline 05 & Water-Cement Ratio & & 0.37 & 0.27 \\
\hline 07 & 20mm:10mm & & $40 \%: 60 \%$ & $40 \%: 60 \%$ \\
\hline 08 & Specific gravity & & $\begin{array}{l}\text { CA:2.68 } \\
\text { FA: } 2.69\end{array}$ & $\begin{array}{l}\text { CA:2.68 } \\
\text { FA: } 2.69\end{array}$ \\
\hline 09 & Water absorption & & CA: $0.5 \%$ FA: $0.6 \%$ & CA: $0.5 \%$ FA: $0.6 \%$ \\
\hline
\end{tabular}


International Journal of Trend in Scientific Research and Development (IJTSRD) ISSN: 2456-6470

\begin{tabular}{|c|c|c|c|c|}
\hline $\begin{array}{l}\text { S. } \\
\text { No. }\end{array}$ & Description of Trial Mix & Unit & Trial Mix No. T5 & Trial Mix No.T6 \\
\hline 10 & Date of Casting & & $29-11-2016$ & $29-11-2016$ \\
\hline \multirow{8}{*}{11} & $\begin{array}{c}\text { Trial Mix Proportions ( for } 9 \\
\text { cubes ) }\end{array}$ & & & \\
\hline & a) Cement & $\mathrm{Kg}$ & 12.37 & 16.95 \\
\hline & b) Water & $\mathrm{Kg}$ & 4.51 & 4.50 \\
\hline & c) Coarse Agg. $-20 \mathrm{~mm}$ & $\mathrm{Kg}$ & 14.50 & 13.09 \\
\hline & d) Coarse Agg. $-10 \mathrm{~mm}$ & $\mathrm{Kg}$ & 21.75 & 19.64 \\
\hline & e) Fine Agg.- & $\mathrm{Kg}$ & 22.02 & 21.54 \\
\hline & g) Admixture Brand & & AURAMIX 200 & AURAMIX 200 \\
\hline & h) Admixture Dosage & & $1.6 \%$ & $1.7 \%$ \\
\hline \multirow{3}{*}{12} & Slump Data : & & & \\
\hline & a) initial & $\mathrm{Mm}$ & 220 & 240 \\
\hline & b) after 30 minutes & $\mathrm{Mm}$ & $2 \times 10$ & 225 \\
\hline \multirow{5}{*}{13} & Compressive Strength & 3 & & \\
\hline & \multirow{4}{*}{$\begin{array}{l}\text { a) } 7 \text { - days strength } \\
\text { b) } 28 \text { days strength }\end{array}$} & $\begin{array}{l}\text { Date of } \\
\text { Testing }\end{array}$ & $6-12-2016$ & $6-12-2016$ \\
\hline & & $\mathrm{MPa}$ & Average $=31.55$ & Average $=50.36$ \\
\hline & & $\begin{array}{l}\text { Date of } \\
\text { Testing }\end{array}$ & $-\square^{27-12-2016}$ & $27-12-2016$ \\
\hline & & $\mathrm{MPa}$ & \begin{tabular}{l|l|}
43.11 & 55.55 \\
\end{tabular} & 65.77 \\
\hline 14 & Avg. Compressive Strength & $\mathrm{MPa}$ & $\begin{array}{llll} & 47.7 & 0\end{array}$ & 65.18 \\
\hline 15 & Compaction factor & f Tre & $\begin{array}{l}\text { Initial:0.948 } \\
\text { Final: } 0.956\end{array}$ & $\begin{array}{l}\text { Intial:0.996 } \\
\text { Final:0.998 }\end{array}$ \\
\hline
\end{tabular}

Comparison between two trials with and without Admixture( at constant w/c ratio)

\begin{tabular}{|c|c|c|c|c|}
\hline & $82=-1$ & & Without Admixture & With Admixture \\
\hline $\begin{array}{l}\text { S. } \\
\text { No. }\end{array}$ & Description of Trial Mix & Unit & Trial Mix No. T1N & Trial Mix No. T2S \\
\hline 01 & Grade of Concrete Mix & $\mathrm{MPa}$ & $M-40$ & $M-40$ \\
\hline 02 & Target Mean Strength & $\mathrm{MPa}$ & 48.25 & 48.25 \\
\hline 03 & Grade of Cement & 0 & $\begin{array}{l}\text { 43GradeOPC TCI } \\
\text { MAX }\end{array}$ & $\begin{array}{r}\text { 43GradeOPC } \\
\text { MAX }\end{array}$ \\
\hline 04 & Name \& Source of Aggregate & 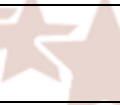 & $\begin{array}{c}\text { CA:LAS JAN FA: } \\
\text { LASJAN }\end{array}$ & $\begin{array}{c}\text { CA:LASJAN FA: } \\
\text { LASJAN }\end{array}$ \\
\hline 05 & Water-Cement Ratio & $\operatorname{lng}^{2}$ & $0 . .35$ & 0.35 \\
\hline 06 & Date of Casting & 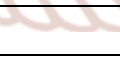 & $30-11-2016$ & $22-11-2016$ \\
\hline 07 & Specific gravity & & $\begin{array}{l}\text { CA: } 2.68 \\
\text { FA: } 2.69\end{array}$ & $\begin{array}{l}\text { CA: } 2.68 \\
\text { FA: } 2.69\end{array}$ \\
\hline 08 & Water absorption & & $\begin{array}{l}\text { CA: } 0.5 \% \\
\text { FA: } 0.6 \% \\
\end{array}$ & $\begin{array}{l}\text { CA: } 0.5 \% \\
\text { FA: } 0.6 \% \\
\end{array}$ \\
\hline 09 & $\begin{array}{l}\text { Trial Mix FOR } 9 \text { CUBES Volume of } \\
9 \text { cubes }=9 \times 0.15 \times .15 \times .15\end{array}$ & & & \\
\hline & a) Cement & $\mathrm{Kg}$ & 17.11 & 13.09 \\
\hline & b) Water & $\mathrm{Kg}$ & 5.94 & 4.50 \\
\hline & c) Coarse Agg. $-20 \mathrm{~mm}$ & $\mathrm{Kg}$ & 12.76 & 9.87 \\
\hline & d) Coarse Agg. $-10 \mathrm{~mm}$ & $\mathrm{Kg}$ & 19.13 & 23.03 \\
\hline & e) Stone dust & $\mathrm{Kg}$ & 19.03 & 24.30 \\
\hline & f) Admixture Brand & & & AUROMIX 200 \\
\hline & g) Admixture Quantity & $\mathrm{Kg}$ & 0 & 0.211 \\
\hline
\end{tabular}


International Journal of Trend in Scientific Research and Development (IJTSRD) ISSN: 2456-6470

\begin{tabular}{|c|c|c|c|c|}
\hline $\begin{array}{l}\text { S. } \\
\text { No. }\end{array}$ & Description of Trial Mix & Unit & Trial Mix No. T1N & Trial Mix No. T2S \\
\hline \multirow{3}{*}{10} & Slump Data : & & & \\
\hline & a) initial & $\mathrm{mm}$ & 30 & 200 \\
\hline & b) after 30 minutes & $\mathrm{mm}$ & 10 & 125 \\
\hline \multirow{5}{*}{11} & Compressive Strength & & & \\
\hline & \multirow[t]{2}{*}{ a) 7- days strength } & \begin{tabular}{|l|} 
Date of \\
Testing
\end{tabular} & $29-11-2016$ & $29-11-2016$ \\
\hline & & Mpa & Average $=30.07$ & Average $=44.33$ \\
\hline & \multirow[t]{2}{*}{ b) 28 - days strength } & \begin{tabular}{|} 
Date of \\
Testing
\end{tabular} & $20-12-2016$ & $20-12-2016$ \\
\hline & & Mpa & \begin{tabular}{|l|l|}
42 & 40.5 \\
\end{tabular} & \begin{tabular}{|l|l|l|}
61.357 .78 & 57.33 \\
\end{tabular} \\
\hline 12 & Avg. Compressive Strength & Mpa & 40.83 & 58.81 \\
\hline 13 & Compaction factor & & $\begin{array}{c}\text { Initial:0.61 Final: } \\
0.75\end{array}$ & Initial:0.953 Final: 0.985 \\
\hline
\end{tabular}

\section{CONCLUSION:}

The net results considering strength criteria can be summarized as:

\begin{tabular}{|c|c|c|c|}
\hline S. No. & Dosage $(\%)$ & W/c & 28 day compressive strength \\
\hline Trial 1 N & 0 & 0.35 & 40.83 \\
\hline Trial 2 N & 0 & 0.37 & 40.50 \\
\hline Trial 1 & 1.6 & 0.35 & 42.81 \\
\hline Trial 2 & 1.6 & 0.35 & 58.81 \\
\hline Trial 3 & 1.6 & 0.35 & 50.95 \\
\hline Trial 4 & 1.7 & 0.35 & 38.67 \\
\hline Trial 5 & 1.6 & 0.33 & 61.03 \\
\hline Trial 6 & 1.6 & 0.30 & 54.81 \\
\hline Trial 7 & 1.6 & 0.37 & 47.7 \\
\hline Trial 8 & 1.6 & 0.27 & 65.18 \\
\hline
\end{tabular}

Now the results considering the workability criteria

\begin{tabular}{|c|c|c|c|}
\hline \multirow{4}{*}{ S.No. } & $\begin{array}{c}\text { Dosage } \\
(\%)\end{array}$ & \multicolumn{2}{|c|}{$\begin{array}{c}\text { Slump value } \\
(\mathrm{mm})\end{array}$} \\
\cline { 3 - 4 } & $0 \mathrm{~min}$ & $30 \mathrm{~min}$ \\
\hline $\begin{array}{c}\text { Trial 1 } \\
\mathrm{N}\end{array}$ & 0 & 30 & 10 \\
\hline $\begin{array}{c}\text { Trial 2 } \\
\mathrm{N}\end{array}$ & 0 & 27 & 9 \\
\hline Trial 1 & 1.6 & 190 & 145 \\
\hline Trial 2 & 1.6 & 200 & 30 \\
\hline Trial 3 & 1.6 & 210 & 51 \\
\hline Trial 4 & 1.7 & 210 & 75 \\
\hline Trial 5 & 1.6 & 230 & 210 \\
\hline Trial 6 & 1.6 & 210 & 175 \\
\hline Trial 7 & 1.6 & 220 & 170 \\
\hline Trial 8 & 1.6 & 240 & 225 \\
\hline
\end{tabular}

Summary, of compactionfactors:

\begin{tabular}{|c|c|c|}
\hline \multirow{2}{*}{ S.No. } & \multicolumn{2}{|c|}{ Compaction factor } \\
\cline { 2 - 3 } Trial 1 N & 0.61 & 0.71 \\
\hline Trial 2 N & 0.54 & 0.71 \\
\hline Trial 1 & 0.963 & 0.983 \\
\hline Trial 2 & 0.953 & 0.985 \\
\hline Trial 3 & 0.954 & 0.968 \\
\hline Trial 4 & 0.984 & 0.990 \\
\hline Trial 5 & 0.975 & 0.990 \\
\hline Trial 6 & 0.987 & 0.993 \\
\hline Trial 7 & 0.948 & 0.956 \\
\hline Trial 8 & 0.996 & 0.998 \\
\hline
\end{tabular}

\section{ECONOMIC VIABILITY:}

This document contains guidelines for the proper use of super plasticizing admixtures also 
known as high-range water reducing admixtures in the production of good quality concrete of flow able consistency. The guidelines presented herein are intended to assist the field personnel in developing a comprehensive Work Plan for the incorporation of super plasticizers in the concrete.

The decision of whether to use super plasticizers should be based on technical and construction considerations for each specific application. This type of admixture, if used properly, can be an advantageous component of the concrete mixture resulting in increased workability, increased strength and ease of placement. If not properly utilized, these admixtures can result in more problems than the situations that led to the consideration of their use. Because the effectiveness of super plasticizers is dependent upon many factors such as field conditions, production equipment, materials and environmental conditions, the Work Plan has to be developed using the same materials and equipment proposed to be used for the job. In addition, field trials must be conducted under similar conditions as those expected during the construction.

The cost of super plasticizer is quite significant at about Rs.120 per litre. This results in a significant increase in the cost. Despite its cost, tremendous savings in labor and production costs can be achieved by using the admixture. Further by using super plasticizer the quantity of cement is reduced, due to which cost decreases further. Thus we can say that super plasticizers would have vast scope.

\section{FINAL CONCLUSION}

An experimental study was carried out to find the effect of super plasticizer on the properties of concrete (M40 at $0.35 \mathrm{w} / \mathrm{c}$ ratio) in fresh and hardened state with variable water reduction and constant water reduction.

The properties tested were

$>$ Slump Retention

$>$ Compressive Strength

$>$ Compaction factors
The results obtained are as follows Without admixture

The compressive strength was obtained to be $\mathrm{MPa}$

$>$ The slump was obtained to be $30 \mathrm{~mm}$ For constant water reduction

$>$ The optimum dosage for compressive strength was found to be $1.6 \%$ admixture quantity (19\% water reduction) with strength of $65.18 \mathrm{MPa}$

$>$ Whereas the optimum dosage for maximum slump retention was found to be $1.6 \%$ admixture quantity (19\% water reduction)

The results obtained can be interpreted as

The work ability of concrete can be increased by addition of super plasticizer however very high dosage of super plasticizer tends to impair the cohesiveness property of concrete.

Compressive strength is improved by super plasticizer; on the other hand its ultimate strength is higher than the desired characteristic strength.

The nstrength of concrete without super plasticizer is found to be greater than the characteristic strength but the slump obtained is less which means that though this concrete will fare well in terms of strength but it is not workable for major works.

Stone dust can be used as an opposite substitute fine aggregate in the case of nonavailability of natural river sand at reasonable cost.

Future scope and recommendations

Following are few recommendations that can be done to further enhance the usefulness of the experiment.

Production of Ultra high strength concrete can be done by further experimenting on the optimum dosage by adding other mineral admixtures such as silica fume, fly ash etc

$>$ Further, the studies can be made to obtain the optimum dosage for different types of admixtures and later on the strength of the same can be increased by adding the mineral admixtures. 
$>$ Comparison between different admixtures can be made to determine which admixture performs better under different exposure conditions.

$>$ Accurate optimum dosage can be obtained by decreasing the dosage difference.

$>$ Further study can be made to manufacture a high strength concrete by increasing the water reduction at optimum dosage.

$>$ Since we have used zone-1 stone dust and boulder crushed coarse aggregate, studies can be carried out using different grades of materials and comparisons can be made accordingly.

$>$ Study can be made on the partial replacement of sand with stone dust.

\section{REFERENCES}

1. Behaviour of High Strength Concrete Using Cement Kiln Dust and Silica Fume. OSR Journal of Mechanical and Civil Engineering (IOSRJMCE) e-ISSN: 2278 1684,p-ISSN: 2320-334X, Volume 14, Issue 2 Ver. V II (Mar. -Apr. 2017), PP 2326

2. EFFECT OF STONE DUST AND FINES ON THE PROPERTIES OF HIGH STRENGTH SELF COMPACTING CONCRETE International Journal of Civil Engineering and Technology (IJCIET) Volume 7, Issue 6, November-December 2016,pp. 393-399,

3. Experimental Investigation on High Performance Concrete with Partial Replacement of Cement by Fly Ash and Fully Replacement of Sand by Stone Dust. International Journal of Constructive Research in Civil Engineering (IJCRCE) Volume 1, Issue 1, June 2015, PP 8-13
4. Optimum usage of Using Met kaolin and Quarry Dust in High Performance Concrete. IOSR Journal of Engineering (IOSRJEN) ISSN (e): 2250-3021, ISSN (p): 2278-8719Vol. 04, Issue 02( February. 2014), ||V1|| PP 56-59

5. Effective Utilization of Crusher Dust in Concrete Using Portland Pozzolana Cement International Journal of Scientific and Research Publications, Volume 3, Issue 8, August 2013 ISSN 2250-3153

6. Behavior of Concrete on Replacement of Sand with Quaries Stone Dust as Fine Aggregate. International Journal of Innovative Research in Science, Engineering and Technology (An ISO 3297: 2007 Certified Organization) Vol. 4, Issue 1, January 2015. ISSN(Online): $2319-8753$

7. Use of Stone Dust as Replacement of Fine Aggregate in Concrete-Review. international Journal of Innovative and Emerging Research in Engineering Volume 3, Issue 9, 2016 e-ISSN: $2394-3343$

8. Development of High Strength Self Curing Concrete Using Super Absorbing Polymer K. Bala Subramanian, A. Siva, S. Swaminathan, Arul. M. G. Aji

9. Study on Strength of Concrete by Partial Replacement of Fine Aggregate with M-Sand and Late rite with Super plasticizers. International Journal of Engineering Trends and Technology (IJETT) -Volume 38 Number 8-August 2016

10. 2.10 An experimental study on high performance concrete using mineral admixtures (C) 2017 IJEDR | Volume 5, Issue 2 | ISSN: 2321-9939 